\title{
Thermal characteristics of permafrost in the steep alpine rock walls of the Aiguille du Midi (Mont Blanc Massif, 3842 m a.s.l)
}

\author{
F. Magnin ${ }^{1}$, P. Deline ${ }^{1}$, L. Ravanel ${ }^{1}$, J. Noetzli ${ }^{2}$, and P. Pogliotti ${ }^{3}$ \\ ${ }^{1}$ EDYTEM Lab, Université de Savoie, CNRS, Le Bourget-du-Lac, France \\ ${ }^{2}$ Glaciology and Geomorphodynamics Group, Department of Geography, University of Zurich, Zurich, Switzerland \\ ${ }^{3}$ ARPA Valle d'Aosta, Saint-Christophe, Italy \\ Correspondence to: F. Magnin (florence.magnin@univ-savoie.fr)
}

Received: 11 March 2014 - Published in The Cryosphere Discuss.: 4 June 2014

Revised: 21 December 2014 - Accepted: 22 December 2014 - Published: 16 January 2015

\begin{abstract}
Permafrost and related thermo-hydro-mechanical processes are thought to influence high alpine rock wall stability, but a lack of field measurements means that the characteristics and processes of rock wall permafrost are poorly understood. To help remedy this situation, in 2005 work began to install a monitoring system at the Aiguille du Midi (3842 $\mathrm{m}$ a.s.l). This paper presents temperature records from nine surface sensors (eight years of records) and three $10 \mathrm{~m}$ deep boreholes (4 years of records), installed at locations with different surface and bedrock characteristics. In line with previous studies, our temperature data analyses showed that: micro-meteorology controls the surface temperature, active layer thicknesses are directly related to aspect and ranged from $<2 \mathrm{~m}$ to nearly $6 \mathrm{~m}$, and that thin accumulations of snow and open fractures are cooling factors. Thermal profiles empirically demonstrated the coexistence within a single rock peak of warm and cold permafrost (about -1.5 to $-4.5^{\circ} \mathrm{C}$ at $10 \mathrm{~m}$ depth) and the resulting lateral heat fluxes. Our results also extended current knowledge of the effect of snow, in that we found similar thermo-insulation effects as reported for gentle mountain areas. Thick snow warms shaded areas, and may reduce active layer refreezing in winter and delay its thawing in summer. However, thick snow thermo-insulation has little effect compared to the high albedo of snow which leads to cooler conditions at the rock surface in areas exposed to the sun. A consistent inflection in the thermal profiles reflected the cooling effect of an open fracture in the bedrock, which appeared to act as a thermal cutoff in the sub-surface thermal regime. Our field data are the first to be obtained from an Alpine permafrost site where borehole temperatures are below $-4^{\circ} \mathrm{C}$, and represent
\end{abstract}

a first step towards the development of strategies to investigate poorly known aspects in steep bedrock permafrost such as the effects of snow cover and fractures.

\section{Introduction}

The last few decades have seen an increase in rockfall activity from steep, high-altitude rock walls in the Mont Blanc Massif (Western European Alps) (Ravanel and Deline, 2010; Deline et al., 2012). Several studies of recent rock avalanches and rockfalls in mid-latitude alpine ranges have ascribed such increases to climate-related permafrost degradation (Deline, 2001; Gruber et al., 2004a; Huggel et al., 2005, 2008; Fischer et al., 2006; Allen et al., 2009; Ravanel et al., 2010, 2012; Deline et al., 2011). Rockfall magnitude and frequency are thought to be linked to the timing and depth of permafrost degradation, which can range from a seasonal deepening of the active layer to long-term, deep-seated warming in response to a climate signal (Gruber and Haeberli, 2007). Local warming of cold permafrost may be induced by advection and the related erosion of cleft ice (Hasler et al., 2011b), which can lead to unexpected bedrock failures. As Krautblatter et al. (2011) noted, before being able to predict permafrost-related hazards, it is necessary to develop a better understanding of the thermo-hydro-mechanical processes involved, which means collecting rock temperature measurements and developing modelling strategies.

Measurement strategies and numerical experiments have been used to investigate the thermal conditions and characteristics of near-vertical and virtually snow-free alpine rock 
walls that are directly coupled with the atmosphere (Gruber et al., 2003, 2004b; Noetzli et al., 2007). These studies have shown the domination of topographical controls on steep bedrock permafrost distribution, with a typical surface temperature difference of $7-8^{\circ} \mathrm{C}$ between south and north faces, the possible coexistence of warm and cold permafrost in a single rock mass, and lateral heat fluxes within the rock mass inducing near-vertical isotherms. Hasler et al. (2011a) suggested that both thin accumulations of snow on micro-reliefs and cleft ventilation may cause deviations of $1^{\circ} \mathrm{C}$ (shady faces) to $3{ }^{\circ} \mathrm{C}$ (sunny faces) compared with the smooth, snow-free rock wall model test cases. The thermal influence of snow on steep rock faces has been addressed via numerical experiments (Pogliotti, 2011), which have shown that the effect of snow is highly variable and depends on topography, and the depth and timing of the accumulation. However, few empirical data are available to evaluate numerical experiments. Recent advances in the study of steep alpine rock walls have helped to build bridges between what is known about the general characteristics of permafrost and processes related to the microtopography and internal structure of rock masses, which may be significant in their short-term evolution and in permafrost distribution. However, a much larger corpus of field observations and monitoring data for a variety of bedrock conditions is needed to develop, calibrate and evaluate reliable models.

As part of our research into geomorphic activity in the Mont Blanc Massif, in 2005 we started a long-term permafrost-monitoring programme at the Aiguille du Midi (AdM), currently the highest instrumented bedrock permafrost site in the European Alps (3842 m a.s.l). This monitoring program was designed to characterize and determine the thermal state of the permafrost and active layer, and to collect temperature data under variable snow-cover and structural conditions that could be used to calibrate and validate high-resolution numerical experiments on permafrost thermal processes.

In this paper we describe the monitoring programme at the $\mathrm{AdM}$, and present temperature data from nine surface miniloggers and three $10 \mathrm{~m}$ deep boreholes. Due to the morphology of the AdM, the monitoring network is concentrated in a very small area; however, the data obtained allowed us to address the following questions:

- How much of the surface temperature variability over this small area is due to topography and snow cover?

- How much of the variability in the active layer is due to the topography of the steep rock walls?

- What are the thermal effects of snow and fractures on sub-surface temperatures at the AdM?

We used 8 years of surface records and 4 years of borehole to analyse seasonal and annual variations in temperature patterns, in the active layer, and in the permafrost thermal regime. We discuss our results in the light of previous

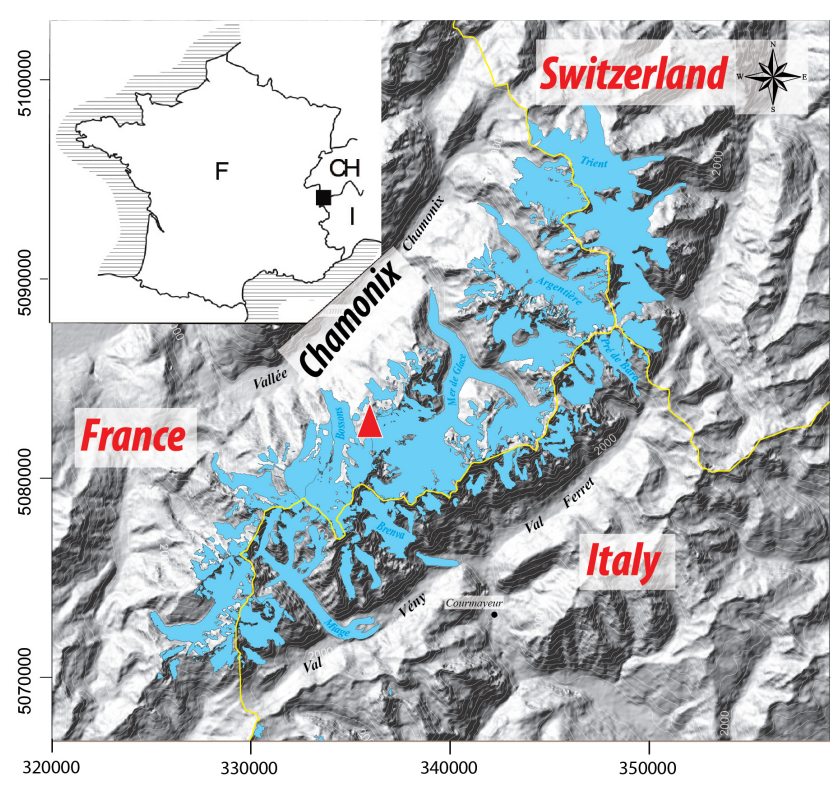

Figure 1. Location of the Mont Blanc Massif and the Aiguille du Midi (red triangle) (modified from Le Roy, 2012).

research and provide new empirical evidence for the effects of snow and fractures on permafrost in steep rock walls.

\section{Study site}

The AdM lies on the NW side of the Mont Blanc Massif (Fig. 1). Its summit $\left(45.88^{\circ} \mathrm{N}, 6.89^{\circ} \mathrm{E}\right)$ consists of three granite peaks (Piton Nord, Piton Central, and Piton Sud) and culminates at $3842 \mathrm{~m}$ a.s.l. The steep and partly glaciated north and west faces of the AdM tower more than $1000 \mathrm{~m}$ above the Glacier des Pélerins and Glacier des Bossons, while its south face rises just $250 \mathrm{~m}$ above the Glacier du Géant (i.e. the accumulation zone of the Mer de Glace). This part of the Mont Blanc Massif is formed by an inclusion-rich, porphyritic granite and is bounded by a wide shear zone. A main, $\mathrm{N} 40^{\circ} \mathrm{E}$ fault network intersected by a secondary network determines the distribution of the main granite spurs and gullies (Leloup et al., 2005). The highest parts of the peak tend to be steep, contain few large fractures, and, in places, are characterized by vertical foliation bands and small fissures. The lower parts are less steep and more fractured. In the present paper we use the abbreviation AdM to refer only to the upper section of the Piton Central, between 3740 and $3842 \mathrm{~m}$ a.s.l. where most of the instruments are installed. A tourist cable car runs from Chamonix to the Piton Nord. Galleries and an elevator allow visitors to gain the viewing platform on top of the Piton Central, from where there is a $360^{\circ}$ panorama of the Mont Blanc Massif.

We chose the AdM as a monitoring site for the following scientific and logistical reasons: (i) permafrost is extremely likely due to the AdM's high altitude and the presence of 


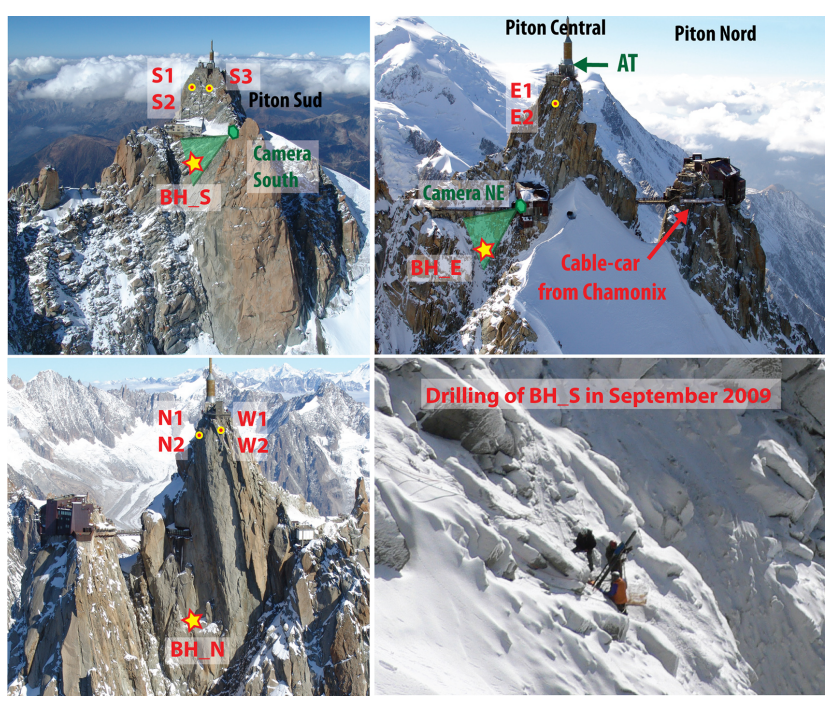

Figure 2. The Aiguille du Midi with snow camera, air temperature, rock surface temperature and borehole logger locations. Pictures: S. Gruber (top left and right, bottom left); P. Deline (bottom right).

cold-based hanging glaciers on its north face; (ii) the morphology of the peak offers a range of aspects, slope angles and fracture densities that are representative of many other rock walls in the massif; (iii) the easy access by cable car from Chamonix and the availability of services (e.g. electricity) at the summit station. Monitoring equipment was installed as part of the PERMAdataROC (2006-2008) and PermaNET (2008-2011) projects, funded by the European Union and run jointly by EDYTEM Lab (France), ARPA VdA (Italy), and the Universities of Zurich (Switzerland), Bonn and Munich (Germany). As such, it complements other rock wall observation sites - for example, those within the Swiss Permafrost Monitoring Network (PERMOS).

Data from the monitoring equipment on the AdM were completed by data from ARPA VdA's weather stations, which measured air temperature and relative humidity, incoming and outgoing shortwave and longwave solar radiation, wind speed, and wind direction on the south and north faces between 2006 and 2010. Electrical Resistivity Tomography (ERT) and Induced Polarization (IP) have been measured since 2008 in conjunction with the universities of Bonn and Munich. High-resolution (cm scale) triangulated irregular networks (TIN) of rock walls and galleries of the AdM were obtained from terrestrial laser scanning. In July 2012, six crack-meters equipped with wireless sensors were installed in major fractures in the Piton Central and Piton Nord in order to complement existing studies of cleft dilatations and shearing movements in rock wall permafrost, to check the stability of the AdM and to test an early warning system. Finally, two GPR surveys were performed along vertical transects in 2013 and 2014. Not all of these data were used in the present study but they will contribute to future research.

\section{Data collection methods}

\subsection{Rock temperature monitoring}

The present study is based on rock surface temperatures taken at the top of the AdM (between 3815 and $3825 \mathrm{~m}$ a.s.l.; Fig. 2) since 2005 by a network of mini-loggers (GeoPrecision PT1000 sensors, accuracy $\pm 0.1^{\circ} \mathrm{C}$ ) installed by the University of Zurich and ARPA VdA. Two loggers were installed in snow-free locations on each face of the AdM (Table 1). The south face has an additional logger (S3) installed just above a small ledge on which snow accumulates in winter, covering the logger. The loggers record the temperature every hour at depths of $0.03,0.30$ and $0.55 \mathrm{~m}$, in line with the method described by Gruber et al. (2003).

In September 2009, three boreholes were drilled in the lower section of the Piton Central, at between 3738 and $3753 \mathrm{~m}$ a.s.l.

In order to minimize possible thermal disturbances caused by air ventilation in the galleries and heating from staff rooms, the boreholes were drilled several tens of metres below the galleries running through the AdM. The criteria used to decide the exact location of each borehole were the aspect, fracturing, roughness and angle of the rock wall (Fig. 2). Each borehole was drilled perpendicular to the rock surface and to a depth of $11 \mathrm{~m}$. Borehole depths were constrained by the drilling equipment and the funding available. The boreholes on the northeast (BH_E) and south (BH_S) faces were drilled in fractured rock walls that slope at 65 and $55^{\circ}$, respectively. Even on rock walls at these angles, snow can accumulate on the micro-reliefs in the face. The borehole on the northwest face (BH_N) was drilled in a vertical, unfractured wall. The only place that snow can accumulate on this wall is on small ledges such as the one above which BH_N was drilled.

The boreholes were drilled between 14 and 27 September 2009 by a team of five people (two mountain guides, plus three members of the EDYTEM Lab) who had to contend with very variable weather and challenging logistics. For each borehole it was necessary to: (i) install a safety line for the workers, (ii) set up a rope system to carry the equipment from the galleries to the drill site, (iii) install a work platform for the three drillers, (iv) anchor a base on which to fix a rack way, (v) drill the hole using a $380 \mathrm{~V}$ Weka Diamond-Core DK 22 electric drill, (vi) insert into the hole a polyethylene PE100 tube (outer diameter: $40 \mathrm{~mm}$; inner diameter: $29 \mathrm{~mm}$ ) sealed at its bottom, and (vii) remove the work platform. In addition to the difficult environment and harsh weather, the drilling work was complicated by the heterogeneity and hardness of the granite, which took a heavy toll on the equipment (11 diamond heads worn out or broken, a dozen steel tubes damaged, and a motor broken). At first we tried to drill $46 \mathrm{~mm}$ diameter boreholes but we had to increase the diameter to $66 \mathrm{~mm}$ so we could use a more robust pipe string. Cooling required 1 to $3 \mathrm{~m}^{3}$ of water per 
Table 1. Instrument positions. BH: borehole thermistor chains, X1 and X2: rock surface temperature loggers, AT: air temperature. Estimated snow accumulation: from automatic cameras and probes for BH_S and BH_E (winter 2012 and 2013), from field observation for S3 and BH_N.

\begin{tabular}{|c|c|c|c|c|c|}
\hline $\begin{array}{l}\text { Site } \\
\text { Code }\end{array}$ & $\begin{array}{r}\text { Elevation } \\
\text { [ma.s.1] }\end{array}$ & $\begin{array}{r}\text { Aspect } \\
{\left[{ }^{\circ}\right]}\end{array}$ & $\begin{array}{r}\text { Slope } \\
{\left[{ }^{\circ}\right]}\end{array}$ & $\begin{array}{l}\text { Sensor } \\
\text { depths }[\mathrm{m}]\end{array}$ & $\begin{array}{r}\text { Estimated } \\
\text { snow } \\
\text { accumulation }[\mathrm{m}]\end{array}$ \\
\hline BH_S & 3753 & 135 & 55 & $\begin{array}{l}0.14,0.34,0.74,1.04,1.34,1.64,2.14,2.64,3.64 \\
4.64,6.64,8.64,9.64\end{array}$ & $>0.8$ \\
\hline BH_N & 3738 & 345 & 90 & $0.3,0.5,0.7,0.9,1.1,1.4,1.7,2,2.5,3,4,5,7,9,10$ & $>1.0$ \\
\hline BH_E & 3745 & 50 & 65 & $0.3,0.5,0.7,0.9,1.1,1.4,1.7,2,2.5,3,4,5,7,9,10$ & $<0.6$ \\
\hline W1 & 3825 & 270 & 80 & 0.1 & 0 \\
\hline S1 & 3820 & 140 & 74 & 0.1 & 0 \\
\hline N1 & 3820 & 354 & 84 & 0.1 & 0 \\
\hline E1 & 3823 & 124 & 60 & 0.1 & 0 \\
\hline N2 & 3820 & 334 & 80 & $0.03,0.1,0.3,0.55$ & 0 \\
\hline $\mathrm{E} 2$ & 3820 & 118 & 60 & $0.03,0.1,0.3,0.55$ & 0 \\
\hline $\mathrm{S} 2$ & 3815 & 160 & 85 & $0.03,0.1,0.3,0.55$ & 0 \\
\hline W2 & 3825 & 270 & 85 & $0.03,0.1,0.3,0.55$ & 0 \\
\hline S3 & 3820 & 158 & 70 & $0.03,0.1,0.3,0.55$ & 0.5 to 1.0 \\
\hline AT & 3845 & 0 & 0 & & 0 \\
\hline
\end{tabular}

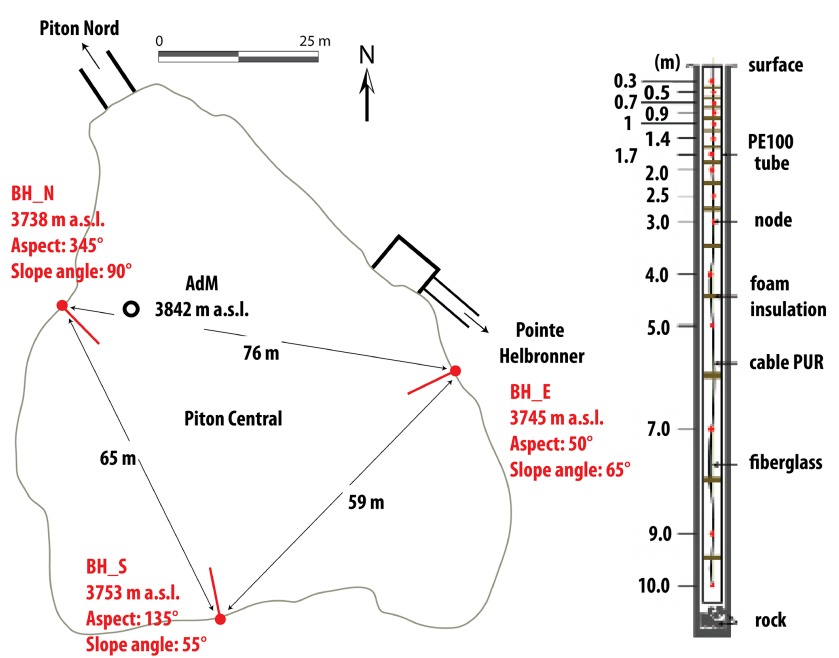

Figure 3. Borehole positions and components. Left: horizontal cross-section through the AdM's Piton Central. Borehole positions are marked in red. Right: $10 \mathrm{~m}$ length, 15 -node thermistor chain installed in the boreholes.

day, which was carried up from Chamonix in $1 \mathrm{~m}^{3}$ tanks via the cable car. Space between the drill hole and the casing was not filled.

The three boreholes were fitted with $10 \mathrm{~m}$ length Stump thermistor chains, each with 15 nodes (YSI 44031 sensors, accuracy $\pm 0.1^{\circ} \mathrm{C}$ ) arranged along a $6 \mathrm{~mm}$ fiberglass rod. Following calibration at $0^{\circ} \mathrm{C}$ in an ice-water basin, the sensors were inserted in BH_S and BH_N in December 2009 and in BH_E in April 2010 (Fig. 3). In order to prevent heat convection, each sensor was separated from the others on the chain by insulating foam. The boreholes were closed at the top, but the chains can be removed to check for thermistor drift. Rock temperatures at depths between 0.3 and $10 \mathrm{~m}$ are recorded every 3 hours (Table 1). Because BH_S is shallower than $10 \mathrm{~m}$, the thermistor chain protrudes from the rock surface by $36 \mathrm{~cm}$. Temperature comparisons between BH_S and BH_N/BH_E were carried out at the closest equivalent depths (e.g. temperatures at a depth of $2.64 \mathrm{~m}$ in BH_S were compared with temperatures at a depth of $2.5 \mathrm{~m}$ in BH_E and BH_N).

\subsection{Air temperature and snow cover measurements}

In order to aid interpretation of the rock temperature data, we collated air temperature data (AT, Table 1) collected by Météo France at a station $3 \mathrm{~m}$ above the top of the Piton Central (3845 m a.s.1.) since 2007. Data prior to 2007 (19892006) are very fragmented due to insufficient equipment maintenance and are not used in this study.

Two automatic cameras have taken six pictures a day of the south and northeast borehole sites since January 2012. In addition, five graduated stakes were placed around each borehole in order to evaluate the spatial variability of snow accumulation from the photographs. Visual analysis of the photos taken during the winters of 2012 and 2013 showed a thick spatially homogeneous snow cover $(>1 \mathrm{~m})$, which lasted until late spring at BH_S, and a thin $(<0.5 \mathrm{~m})$ spatially variable snow cover at the BH_E, where the rock face is much steeper and more complex (Table 1). Snow accumulations at BH_N and S3 were estimated from field observations. Accumulations of snow at $\mathrm{BH} \_\mathrm{N}$ were restricted to the relatively large ledge above which the borehole is drilled. This snow patch was over $1 \mathrm{~m}$ thick for most of the year. $\mathrm{S} 3$ is also frequently covered by $>0.5 \mathrm{~m}$ of snow, which accumu- 
Table 2. Data availability after gap filling. Wi: December, January, February; Sp: March, April, May; Su: June, July, August; Fa: September, October, November. Red sections indicate where gaps $<1.5$ month per year have been filled in order to calculate annual means (seasonal means not calculated for the concerned seasons). For time series that are interrupted (empty boxes) the annual mean is not computed for the concerned years.

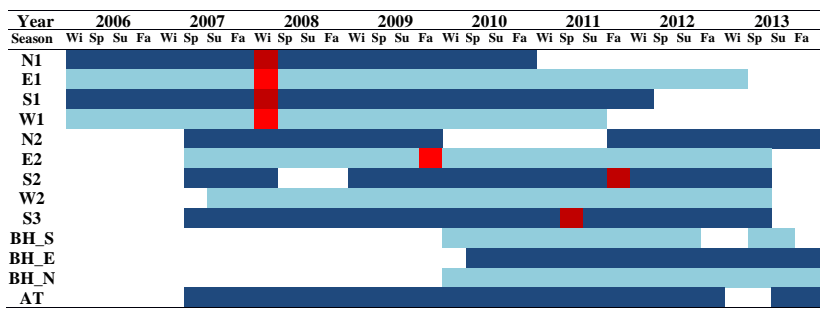

lates during winter and spring on the small ledge above the sensor. Snow depth is more variable at S3 than at BH_N because the intense solar radiation at $\mathrm{S} 3$ leads to more frequent melting.

\section{Data set preparation}

The borehole time series were all continuous except for short periods for BH_S, as this logger was removed from September 2012 to January 2013 and from October 2013 to January 2014 to prevent it being damaged by engineering work close to the borehole. Gaps in the $0.3 \mathrm{~m}$ temperature and AT time series were filled in so we could calculate seasonal and annual means (see Table 2). First, we calculated daily means from rock temperature time series for days with complete records. Then, we filled short gaps ( $<5$ days) by linear interpolation between the nearest available data points for the same depth. Longer gaps (up to 1.5 month) were filled by replacing missing data with the average value for the 30 days before and 30 days after the gap (see Hasler et al., 2011a). To fill the longest gaps for E1, N1, S1, and W1 (from 4 December 2007 to 7 February 2008) we used a third approach that involved applying a linear regression equation, fitted using data from each pair of loggers (e.g. E2 and E1) and records for the missing periods (i.e. December-February) from groups of years with complete records (2006-2007 and 2008-2009). Correlation coefficients for the equations ranged from 0.89 (S1 and S2) to 0.94 (E1 and E2). We tested this approach by simulating corresponding gap periods in the years with complete data and then filling these gaps using the regression equations. Differences between the annual means obtained using this method and the annual means calculated from the complete data set were in the range $0.01-0.15^{\circ} \mathrm{C}$ and can be considered negligible. Our calculations of seasonal means did not include data obtained using the 30-day average or linear regression methods. The longest gap we filled in any 1 year was $<1.5$ months, in line with standard practice for the PERMOS network (personal communication, 2014).

\section{Rock surface temperature}

Smith and Riseborough (2002) defined Surface Offset (SO) as the difference between local air temperature and ground surface temperature. SO is a parameter in the TTOP model (Temperature at the Top of Permafrost, Smith and Riseborough, 1996), originally developed to define the functional relation between air and ground temperatures in polar lowlands and later applied to high-latitude mountainous terrain (Juliussen and Humlum, 2007). SO can be used to quantify the overall effect of ground cover and ground surface parameters on the surface energy balance.

We calculated annual SOs (ASO), using mean annual air temperature (MAAT) and mean annual ground surface temperature (MAGST), and seasonal SOs (SSO) from seasonal means for winter (December to February), spring (from March to May), summer (from June to August) and fall (from September to November), using time series measured at depths of $0.3 \mathrm{~m}$ (boreholes and E2, S2, W2, N2) and $0.1 \mathrm{~m}(\mathrm{E} 1, \mathrm{~S} 1, \mathrm{~W} 1, \mathrm{~N} 1)$ - points we considered representative of surface conditions. We applied a standard lapse rate of $0.006{ }^{\circ} \mathrm{C} \mathrm{m}^{-1}$ to air temperatures in order to balance the elevation difference between the Météo France station and the sensors. Figure 4 shows ASOs for all the complete years (Fig. 4a), SSOs for snow-free sensors for the available seasons (Fig. 4b), and SSOs for snow-covered sensors for the available seasons (Fig. 4c). We also analysed daily temperature records for the snow-covered sensors and air temperature trends as part of our investigation of the effect of snow cover on snow temperatures (Fig. 5).

\subsection{Surface offset patterns}

Maximum and minimum ASOs were $9.3^{\circ} \mathrm{C}$ at $\mathrm{S} 1$ in 2011 , and $1.3{ }^{\circ} \mathrm{C}$ at $\mathrm{N} 1$ in 2009 (Fig. 4a). These are typical values for the Alps (PERMOS, 2013). On the south face, the snow-covered sensors gave lower values than the snowfree sensors. For example, the ASOs for S3 were between $0.1^{\circ} \mathrm{C}(2010)$ and $1.4^{\circ} \mathrm{C}$ (2011) lower than the ASOs for $\mathrm{S} 1$. Conversely, on the north side, the snow-covered sensor gave higher ASOs than the snow-free sensors. On a seasonal timescale, the maximum SSOs occurred in summer for the snow-free sensors (Fig. 4b), except for the sensors on the south face (S1 and S2), where the maximum SSOs occurred in spring, with values $>10^{\circ} \mathrm{C}$. The lowest SSOs were recorded in winter, and ranged from approximately $8^{\circ} \mathrm{C}$ on the south face to $<1{ }^{\circ} \mathrm{C}$ on the north face (N1 and N2). SSO patterns for the snow-covered sensors (Fig. 4c) were opposite to those for the snow-free sensors, except for BH_E. At BH_N and BH_S, SSOs were largest in winter (4.1 and $9.5^{\circ} \mathrm{C}$, respectively) and lowest in summer. At $\mathrm{S} 3$, the largest 

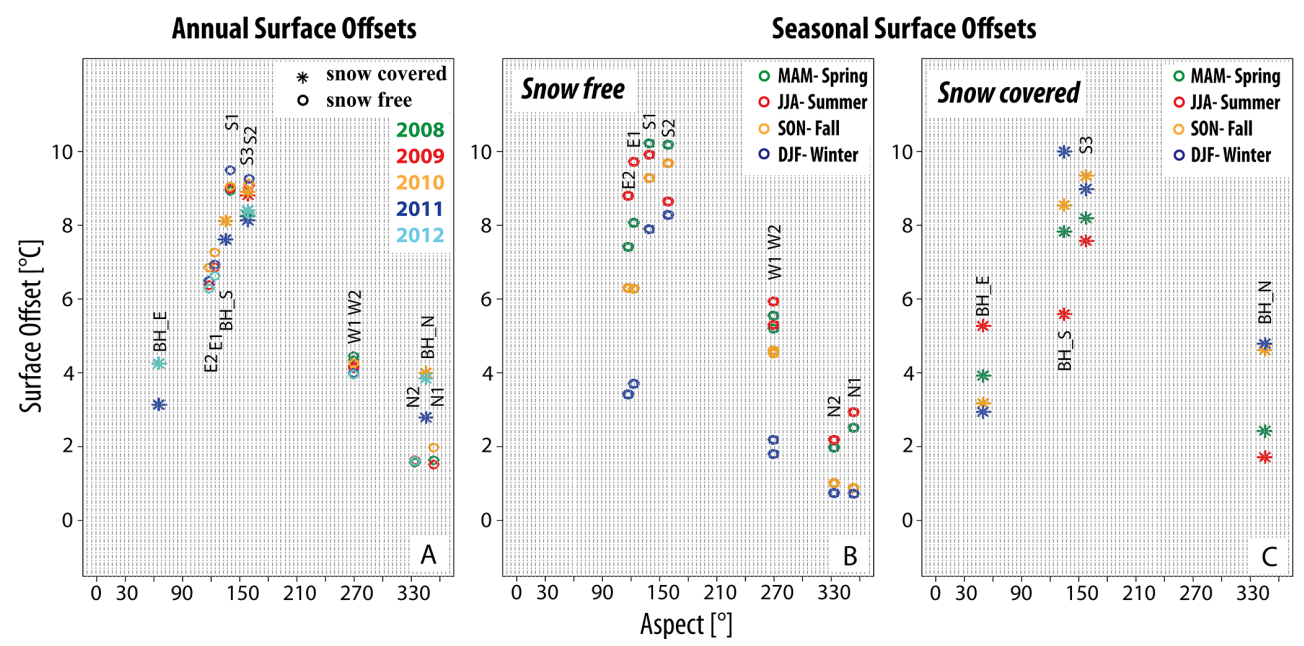

Figure 4. Annual and seasonal surface offsets calculated from sensors at $0.3 \mathrm{~m}$ depth. ASOs are shown for all the available years. SSOs are the mean values for the available seasons for each logger listed in Table 2.

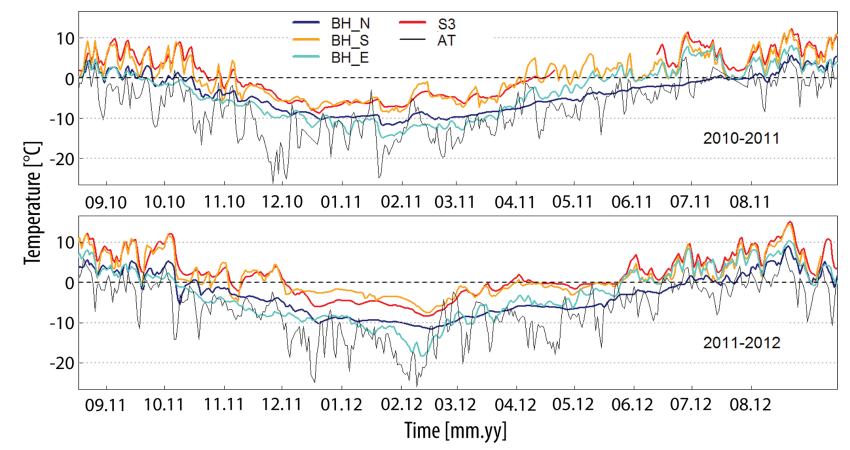

Figure 5. Daily temperature records at $0.3 \mathrm{~m}$ depth for snowcovered sensors for the 2010-2011 and 2011-2012 hydrological years.

SSO was in the fall. Fall SSOs were also relatively high at BH_N and BH_S. In contrast to SSOs at other snow-covered sensors, SSOs at BH_E followed a similar pattern to that recorded at the snow-free sensors, in that SSO values were directly related to insolation duration.

From 2011 to 2012, the changes in ASO at snow-covered and shady sensors such as BH_E and BH_N were greater $\left(+1.1^{\circ} \mathrm{C}\right)$ than they were at the snow-covered and southfacing sensors (only $+0.3^{\circ} \mathrm{C}$ at S3). Conversely to the snowcovered sensors, the ASO decreased at the snow-free sensors from 2011 to 2012 , with, for example, values of $-1{ }^{\circ} \mathrm{C}$ at $\mathrm{S} 2$ and $-0.3{ }^{\circ} \mathrm{C}$ at $\mathrm{E} 1$. The maximum and minimum ASOs for the different snow-free sensors varied with aspect, with, for example, maximum ASOs in 2008 at W1 and W2, but in 2011 at S1 and S2.

\subsection{Daily temperatures at snow-covered sensors}

Daily temperature curves for the snow-covered sensors are smoothed compared to air temperature oscillation during cold periods (Fig. 5). The S3 and BH_S temperature curves were strongly smoothed from mid-November 2010 to January (BH_S) or April 2011 (gap for S3), and from early December 2011 to mid-May 2012. Both sensors recorded a period of almost constant $0^{\circ} \mathrm{C}$ conditions from April to midMay 2012. The temperature curve for BH_N was strongly smoothed until the summer, with a similar constant $0^{\circ} \mathrm{C}$ period for three weeks in July 2011. Although the BH_E temperature curve from late September to February-March was mostly smoother than daily air temperature curve, the two curves were more closely coupled than they were at the other sensors, as the oscillations in temperatures at BH_E were in-synch with major changes in AT, such as the large drop in temperature in December 2012. From September 2010 to March 2011 and from November 2011 to February 2012, the temperatures recorded at BH_E were lower than those recorded at BH_N.

\subsection{Snow cover and micro-meteorological influences}

Normally on steep, snow-free bedrock in the high mountains, the MAGST is higher than MAAT, mainly because of direct solar radiation (Gruber et al., 2004b) but also due to a contribution from reflected solar radiation from large, bright glacier surfaces below measurement points (PERMOS, 2013). In the European Alps, the ASO can be up to $10^{\circ} \mathrm{C}$ on south-facing rock walls, whereas the maximum ASO values recorded on steep rock walls in Norway are only $3{ }^{\circ} \mathrm{C}$, as there is less direct solar radiation at higher latitudes (Hipp et al., 2014). In New Zealand, at similar latitude to the Alps, Allen et al. (2009) reported a maximum ASO value 
of $6.7^{\circ} \mathrm{C}$. This lower value is probably the result of reduced direct solar radiation due to the influence of the oceanic climate and related frequent cloud cover. Most of the surface sensors used in the above studies were installed in snowfree conditions in order to test energy balance models (Gruber et al., 2004b) or for statistical fitting (Allen et al., 2009; Boeckli et al., 2012). At the AdM, the ASO patterns of snowcovered sensors at snow-covered sensors differed from those at snow-free sensors, mainly due to decoupling from atmospheric conditions during the winter season and the lower surface albedo of the snow-free sensors.

The differences in ASOs between snow-covered and snow-free sensors on similar aspects show that snow has a substantial effect on the annual energy balance. According to empirical and numerical studies (Hanson and Hoelzle, 2004; Luetschg et al., 2008), snow cover must be at least $0.6-0.8 \mathrm{~m}$ thick to insulate the rock surface from the air temperature, but snow cover on steep rock walls is usually thinner than this insulating threshold (Gruber and Haeberli, 2009). The differences between BH_N and BH_E in terms of ASOs and SSOs can probably be ascribed to variations in mean snow cover thickness (Table 1), and demonstrate that the insulating effect of snow can occur locally also in steep rock walls. On the north face, ASOs were higher at snow-covered sensors (BH_N) than at snow-free sensors (N1 and N2), showing that thermo-insulation by snow significantly increases the MAGST. On the south face, ASOs were lower at the snowcovered sensors (BH_S and S3) than at the snow-free sensors (S1 and S2), indicating that snow lowers the MAGST. This reduced warming effect could result from the combination of (i) thin snow cover with negligible thermo-insulation, (ii) a higher surface albedo, and (iii) melt energy consumption (Harris and Corte, 1992; Pogliotti, 2011). The latter two factors seem to be prevalent at the AdM because snow cover on the south face is often greater than $1 \mathrm{~m}$ thick during winter (Sect. 3.2) leading to a marked smoothing of daily temperature oscillations (Fig. 5). These results extend previous studies on thin snow accumulations (Hasler et al., 2011a). The importance of this reduced warming effect on sunny faces is probably reinforced by the fact that snow is present for much of the year at such altitudes, as suggested by (i) the high fall SSOs (early snow accumulation) for snow-covered sensors, (ii) their low summer SSOs, and (iii) by the nearly constant temperature close to $0^{\circ} \mathrm{C}$ in late summer (Fig. 5). This constant $0{ }^{\circ} \mathrm{C}$ temperature may reflect the zero-curtain effect, which results in the snow melting and retards the thawing of the active layer, as has been described for snow-covered gentle mountain slopes (e.g. Hanson and Hoelzle, 2004; Gubler et al., 2011).

Different interannual changes were recorded at snowcovered and snow-free sensors. The PERMOS study (2013) has reported analogous differences in interannual variability between rock walls and gentle snow-covered terrain. Interannual changes at the snow-free sensors were mainly related to differences in insolation due to cloud cover. It may be that differences in interannual changes from one aspect to another are also due to variations in cloud formation from year to year. Energy balance models have shown that convective cloud formation can cause differences in the spatial distribution of MAGST over a single rock peak (Noetzli et al., 2007). On shady faces, the effect of solar radiation control is greatly reduced and snow cover may be the most important factor affecting interannual changes. Consequently, the temperature at a snow-covered sensor can increase from one year to the next if snow insulation from the atmospheric temperature increases, while the temperature at a snow-free sensor may drop due to reduced insolation. In the case of sun-exposed and snow-covered sensors, such as S3, the balance between warming and cooling effects leads to smaller interannual ASO changes than at sensors in shadier locations, where temperature are mostly controlled by the warming effect of snow insulation. Thus, the influence of snow cover on the surface temperature of high-altitude rock walls is a due to a combination of topography, snow depth and micrometeorology.

\section{Borehole records}

Four years of data from the three boreholes allowed us to describe daily temperature patterns (Fig. 6), mean annual temperature-depth $(T(z))$ profiles, and annual temperature envelopes (i.e. the maximum and minimum daily temperatures at each depth in 2011; Fig. 7). We focused on the active layer and the permafrost thermal regime, paying special attention to thermal effects related to snow cover and bedrock structure. We discuss their possible influence on the active layer and bedrock thermal regime.

\subsection{Active layer}

Active layer thickness (ALT) varied with aspect, with means of ca. $3 \mathrm{~m}$ at BH_E, $5.5 \mathrm{~m}$ at BH_S, and $2.2 \mathrm{~m}$ at BH_N (Fig. 6). Interannual variability during the monitoring period was ca. $0.7 \mathrm{~m}$ for each borehole (Table 3). Maximum ALTs occurred in 2012 at BH_N (2.5 m deep) and in 2013 at BH_E (3.4 $\mathrm{m}$ deep). At BH_S, data are missing for 2012 and 2013, but 2010 and 2011 data show a maximum ALT in 2011 of $5.9 \mathrm{~m}$. The length of the thawing period, marked by continuous positive temperatures at the uppermost thermistor, also varied according to aspect. It was longest at BH_S, starting in June (April in 2011), but with isolated thawing days already in March (e.g. in 2012). In general, the surface at BH_S refroze in October, but total refreezing of the active layer did not occur until December in 2010 and 2011. The 2011-2012 freezing period was particularly mild and short (3-4 months) at BH_S. This pattern was not as marked at BH_E, which even recorded its lowest surface temperature in 2011-2012. BH_N had the longest freezing periods because temperatures in the rock sub-surface remained positive only 


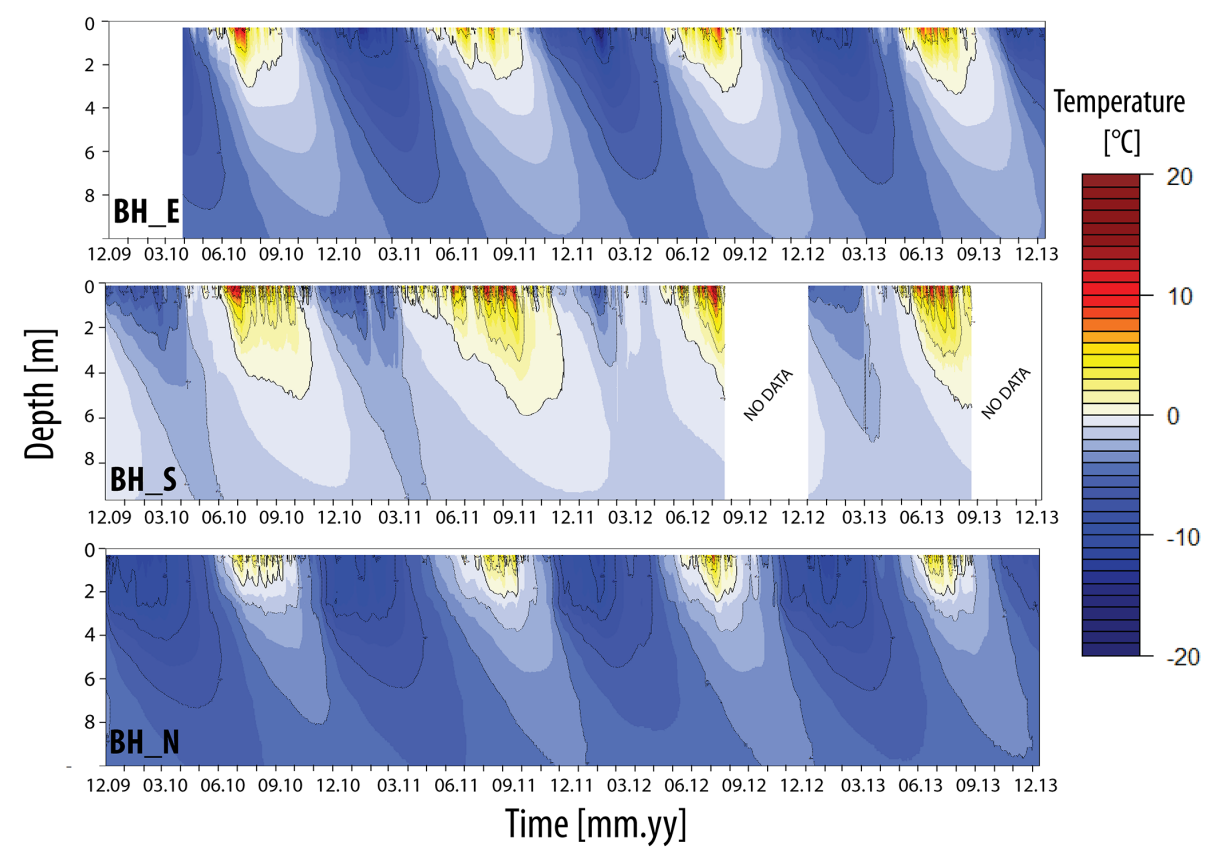

Figure 6. Daily temperature records in the AdM boreholes from December 2009 to December 2013.
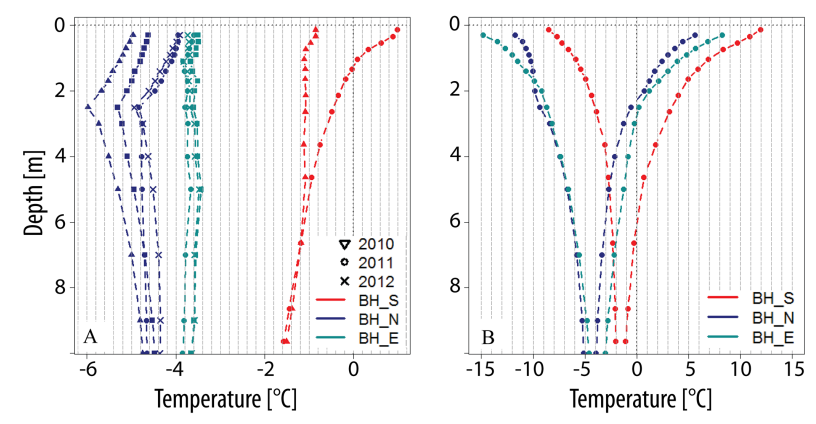

Figure 7. Mean $T(z)$ profiles $(A)$ and 2011 temperature envelopes $(B)$ of the AdM boreholes.

from June to October. In 2011, thawing did not start until August. BH_E had the most balanced thawing and freezing periods (ca. 6 months each).

The timing of maximum ALT depended on aspect and year (Table 3). In 2010 and 2011, maximum ALT occurred earliest at BH_E, even though the active layer was thicker at BH_E than at BH_N. In 2012 and 2013, BH_N was the first site to reach maximum ALT. In 2010, maximum ALT at BH_S occurred very late, 3 months after BH_E. Although the BH_S active layer had mostly thawed by mid-July, thawing continued steadily until the end of October. Maximum ALT always occurred later at BH_S than at the other boreholes, but the lowering of the $0^{\circ} \mathrm{C}$ isotherm was more linear.

\subsection{Thermal regime}

Annual temperature-depth $T(z)$ profiles (Fig. 7a) revealed different thermal regimes. The AdM's Piton Central has both warm (ca. $-1.5^{\circ} \mathrm{C}$ at BH_S) and cold (ca. $-4.5^{\circ} \mathrm{C}$ at BH_N) permafrost (Table 3 ). Interannual changes were not similar in every borehole. In BH_N and BH_E, the changes over 20102013 generally followed the changes in MAAT all along the $T(z)$ profiles. For example, the $T(z)$ profiles show considerable warming from 2010 to 2011 in response to the $2.3^{\circ} \mathrm{C}$ rise in MAAT (Table 3). The BH_N $T(z)$ profile in 2011 was significantly warmer than in other years for depths up to $2.5 \mathrm{~m}$; however it was colder than 2012 for depths greater than $3 \mathrm{~m}$ and colder than 2013 for depths greater than $7 \mathrm{~m}$. In BH_S, the mean annual $T(z)$ profile for 2011 showed remarkably high temperature near the surface with positive temperatures up to a depth of $1 \mathrm{~m}$. Temperatures were higher than in 2010 for the shallowest $6 \mathrm{~m}$ of the profile but slightly lower than in 2010 below this depth.

The zero annual amplitude depth is $>10 \mathrm{~m}$ for every borehole (Fig. 7b), which is consistent with other bedrock sites in the European Alps (PERMOS, 2007). In 2011, the largest amplitudes in daily temperature (peak to peak) at the surface $\left(>20^{\circ} \mathrm{C}\right)$ and at $10 \mathrm{~m}$ depth $\left(1.6^{\circ} \mathrm{C}\right)$ were at BH_E, and the smallest surface $\left(15.5^{\circ} \mathrm{C}\right)$ and $10 \mathrm{~m}\left(1.0^{\circ} \mathrm{C}\right)$ amplitudes were at BH_N and BH_S, respectively. In line with the surface pattern, the minimum $T(z)$ profile from the surface to $1.4 \mathrm{~m}$ depth was warmer at BH_N than at the sunnier BH_E (Fig. 7b).

The minimum and mean annual $T(z)$ profiles for BH_N contain two distinct sections separated by an inflection at 
Table 3. Borehole and air temperature records. ALT: active layer thickness. MART $10 \mathrm{~m}$ : mean annual rock temperature at $10 \mathrm{~m}$ depth. MAAT: mean annual air temperature.

\begin{tabular}{|c|c|c|c|c|c|c|c|c|c|c|}
\hline \multirow[t]{2}{*}{ Year } & \multicolumn{3}{|c|}{ BH_E } & \multicolumn{3}{|c|}{ BH_S } & \multicolumn{3}{|c|}{ BH_N } & \multirow[b]{2}{*}{$\begin{array}{r}\text { MAAT } \\
{\left[{ }^{\circ} \mathrm{C}\right]}\end{array}$} \\
\hline & $\begin{array}{r}\text { ALT } \\
{[\mathrm{m}]}\end{array}$ & $\begin{array}{r}\text { Max. ALT } \\
\text { [dd mm] }\end{array}$ & $\begin{array}{r}\operatorname{MART}_{10 \mathrm{~m}} \\
{\left[{ }^{\circ} \mathrm{C}\right]}\end{array}$ & $\begin{array}{r}\text { ALT } \\
{[\mathrm{m}]}\end{array}$ & $\begin{array}{r}\text { Max. ALT } \\
\text { [dd mm] }\end{array}$ & $\begin{array}{r}\operatorname{MART}_{10 \mathrm{~m}} \\
{\left[{ }^{\circ} \mathrm{C}\right]}\end{array}$ & $\begin{array}{r}\text { ALT } \\
{[\mathrm{m}]}\end{array}$ & $\begin{array}{r}\text { Max. ALT } \\
\text { [dd mm] }\end{array}$ & $\begin{array}{r}\operatorname{MART}_{10 \mathrm{~m}} \\
{\left[{ }^{\circ} \mathrm{C}\right]}\end{array}$ & \\
\hline 2010 & 3.1 & 27.07 & - & 5.2 & 23.10 & -1.4 & 1.8 & 28.08 & -4.7 & -9 \\
\hline 2011 & 2.7 & 30.08 & -3.8 & 5.9 & 22.10 & -1.5 & 2.3 & 18.09 & -4.6 & -6.7 \\
\hline 2012 & 3.3 & 26.08 & -3.6 & - & - & - & 2.5 & 26.08 & -4.3 & -7.7 \\
\hline 2013 & 3.4 & 08.09 & -3.6 & 5.8 & 30.09 & - & 2.2 & 25.08 & -4.5 & - \\
\hline
\end{tabular}

ca. $2.5 \mathrm{~m}$ deep (Fig. 7a). This coincides with an $8-10 \mathrm{~cm}$ width cleft encountered at this depth during the drilling operation. The temperature gradient is negative $\left(-0.39^{\circ} \mathrm{C} \mathrm{m}^{-1}\right)$ from the surface to the cleft, and then positive from the cleft to $10 \mathrm{~m}$ deep (from $0.16^{\circ} \mathrm{C} \mathrm{m}^{-1}$ to nearly isothermal). The mean annual profiles for BH_E are almost linear and have a temperature gradient of ca. $-0.02^{\circ} \mathrm{C} \mathrm{m}^{-1}$. In the case of BH_S, the upper parts of the annual $T(z)$ profiles for 2010 and 2011 differ greatly, with an almost linear temperature gradient of $-0.07^{\circ} \mathrm{C} \mathrm{m}^{-1}$ in 2010 , and a much steeper overall temperature gradient of $-2.26^{\circ} \mathrm{C} \mathrm{m}^{-1}$ in 2011 .

\subsection{Snow cover and bedrock discontinuity controls}

The coexistence of warm and cold permafrost, and the opposite temperature gradients at $\mathrm{BH} \_\mathrm{S}$ and $\mathrm{BH} \_\mathrm{N}$, probably due to lateral heat fluxes, are in accordance with the results of numerical simulations (Noetzli et al., 2007).

In terms of the permafrost thermal regime, the values recorded at BH_N were below $-4{ }^{\circ} \mathrm{C}$, which is a value typical for high-latitude monitoring sites, such as those in Svalbard (Noetzli et al., 2014a), and the warmest boreholes of the continuous permafrost zone in Alaska (Romanovsky et al., 2014).

The spatial and temporal variability of ALT is consistent with values reported for Swiss boreholes in bedrock (PERMOS, 2013). For example, the thickness and timing of the ALT in BH_E are similar to those recorded at the Matterhorn-Hörnligrat site (3295 m a.s.l, vertical borehole on a crest), with values ranging from 2.89 to $3.66 \mathrm{~m}$ between 2008 and 2010, and with maximum ALT occurring between early September and early October. Early studies considered that in bedrock slopes, changes in ALT are strongly controlled by summer air temperature, as indicated by the ALT at Schilthorn (2909 $\mathrm{m}$ a.s.l) which was twice as thick as usual (from 4-5 $\mathrm{m}$ to $>8 \mathrm{~m}$ ) during the hot summer of 2003, while there was no unusual increase in the ALT under the debris-covered slopes, such as Les Gentianes moraine and the Arolla scree slopes, located in the same area and at similar altitude (PERMOS, 2013).

The different patterns of ALT variability at the three AdM boreholes (Table 3) suggest that the air temperature is not the only controlling factor. The relatively mild and short 20112012 freezing period at BH_S may have been due to snow insulation, as suggested by the subsequent period of constant temperature from the surface to a depth of $3 \mathrm{~m}$ (Fig. 6). This isothermal period coincided with the zero-curtain effect observed at the surface temperature from April to midMay 2012 (see Sects. 5.2 and 5.3, Fig. 5). As reported by Hoelzle et al. (1999), thick, long-lasting snow cover reduces both freezing of the active layer by insulating it from low temperatures and thawing of the active layer by late snow melting. Such an effect on the active layer freeze-thaw cycles has been reported by studies in gentle mountain terrains, but has not been observed in steep bedrock permafrost (Gruber et al., 2004a). A comparison of temperature variations at BH_E and BH_N clearly shows the effect of snow insulation (Fig. 5). Most notably, winter surface temperatures are always warmer and less variable at BH_N than at BH_E (Fig. 5) and at depth (Fig. 7b). Snow appears to have a warming effect at depths of up to $1.4 \mathrm{~m}$. In terms of ALT, the different trends between BH_E and BH_N during the period 2011-2013 (Table 3) may be due to the effect of long-lasting snow cover at BH_N modifying its response to the climate signal. Conversely, the reduced ALT at BH_E in 2011, in contrast with BH_S and BH_N, may be the result of variations in the effect of summer snow fall on these different faces. Unfortunately, the cameras and snow stakes that would have allowed us to check this hypothesis were not installed in 2012 (Sect. 3.2). Further studies are needed to verify this hypothesis.

According to a modelling study, the interannual variability of ALT is greater on sun-exposed faces, as they respond as much to change in air temperature as to changes in solar radiation (Gruber et al., 2004a). However, our data did not conform to this prediction, as the change in ALT at BH_S was similar to the ALTs at the shadier BH_E and BH_N. Furthermore, BH_S experienced the smallest interannual changes at $10 \mathrm{~m}$ depth, and the shape of its $T(z)$ profiles between 2010 and 2011 did not follow the trend of the MAAT signal at depths between 6 and $10 \mathrm{~m}$. This may be due to the consumption of latent heat. In fact, previous studies have attributed the delaying and dampening effect of latent heat consumption to the thermal response of bedrock permafrost (Kukkonen and 


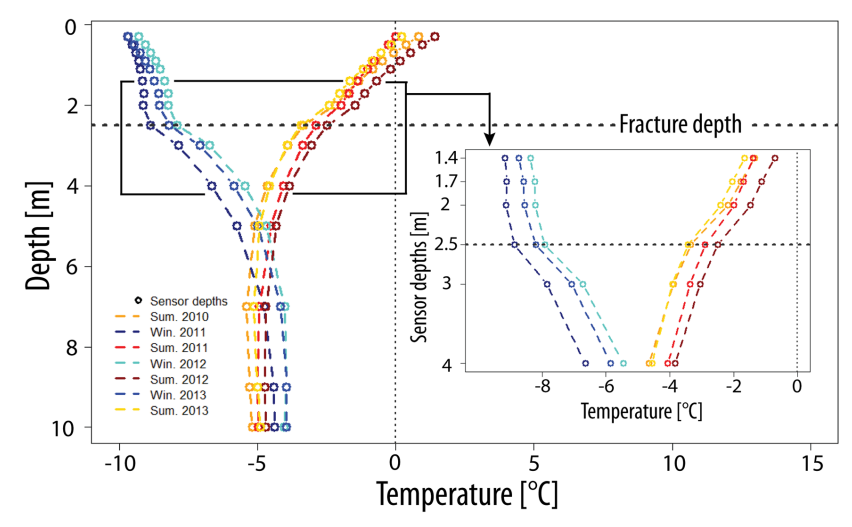

Figure 8. Seasonal $T(z)$ profiles for winters (December to February) and summers (June to August) recorded in BH_N.

Safanda, 2001; Wegmann et al., 1998; Noetzli et al., 2007). Field observations during drilling revealed the presence of wet-detritic materials in the fractures in BH_S, suggesting that latent heat may be consumed by phase changes between interstitial water and ice. Evidence for latent heat consumption at BH_S is supported by the temperatures in the borehole, which are around the values required for phase-change processes. Snow accumulation and melting on the south face are an obvious source of water to supply bedrock discontinuities.

Interannual changes at $\mathrm{BH} \_\mathrm{E}$ and $\mathrm{BH} \_\mathrm{N}$ followed variations in MAAT all along their profiles (except for BH_N in 2011) suggesting that latent heat consumption did not occur (Fig. 7a). From 2010 to 2011 the BH_N T(z) profile warmed significantly above the cold inflection. This followed MAAT (Table 3), but the colder conditions below the inflection were not in accordance with the climate signal. Hence, the fracture seems to act as a thermal cutoff between the surface layer and the deep bedrock. The sharp inflection in the profiles at the fracture depth, which is especially prominent in the mean and minimum annual $T(z)$ profiles, indicates that the fracture locally cools the rock. Mean annual temperature is even lower at depth of $2.5 \mathrm{~m}$ than it is at the surface, which, as explained above, is probably insulated by the snow cover. Seasonal temperature profiles for BH_N (Fig. 8) show a relatively large difference between the temperature gradient above and below the fracture depth during winter (December to February) and a much smaller difference during summer (June to August). In winter, the temperature gradient above the fracture depth was quite low (between 0.5 and $0.9^{\circ} \mathrm{C} \mathrm{m}^{-1}$ between 0.3 and $2.5 \mathrm{~m}$, depending on the year), but much higher at greater depth (between 5.1 and $6{ }^{\circ} \mathrm{C} \mathrm{m}^{-1}$ between 2.5 and $3 \mathrm{~m}, 6.3^{\circ} \mathrm{C} \mathrm{m}^{-1}$ between 3 and $4 \mathrm{~m}$, and $>4{ }^{\circ} \mathrm{C} \mathrm{m}^{-1}$ down to $7 \mathrm{~m}$ ). In summer the difference in temperature gradients was much less marked, although there was still a substantial change in temperature gradient at the fracture depth. The mean gradient stepped up from between $-1.4^{\circ} \mathrm{C}$ and $-2{ }^{\circ} \mathrm{C} \mathrm{m}^{-1}$ between 0.3 to $2 \mathrm{~m}$ depth, to between -2.3 to $-5.1^{\circ} \mathrm{C} \mathrm{m}^{-1}$ between 2 and $2.5 \mathrm{~m}$ depth. The temperature gradient remained relatively high $\left(>2.4^{\circ} \mathrm{C} \mathrm{m}^{-1}\right.$ except in 2010) up to $4 \mathrm{~m}$ depth, and then progressively decreased. These observations suggest that the fracture provokes a heat sink, with greater downward propagation in winter, and a more localized effect in summer. This cooling effect may be due to air ventilating through the open fracture, a process that has been shown to have an important cooling effect on steep rock wall permafrost (Hasler et al., 2011a). In our study this cooling effect was greater when the air temperature was low. Nevertheless, despite this cooling effect, water percolation can occur along the fracture and heat advection could locally warm the rock (Hasler et al., 2011b). However, the temperature data for BH_N do not provide any evidence for this. The temperature profile for BH_E is generally linear indicating that conduction is the dominant heat transfer process (Williams and Smith, 1989). Thus, active layer thickness and timing and permafrost temperatures at the AdM are controlled by a number of factors that interact with each other, including snow cover, latent heat consumption (which delays and dampens short-term responses to climate signals), and cooling effect due to air ventilation within open fractures.

\section{Conclusions}

The high altitude, morphology and accessibility of AdM make it an exceptional site for investigating permafrost in steep rock walls. A monitoring network installed on the AdM to investigate the thermal effects of topography, snow cover and fractures on permafrost provided 8 years of rock surface temperature and 4 years of borehole temperature data. The results of our analyses of this new data set supported the findings of previous field studies and a number of numerical experiments:

- The thermal characteristics of the AdM's rock walls are typical of steep bedrock permafrost. The spatial variability of surface temperature, active layer thickness and timing, and the permafrost thermal regime are mainly controlled by topography.

- Borehole temperature data confirm the characteristics of the sub-surface thermal regime predicted by numerical experiments, in particular the coexistence within a single rock peak of warm and cold permafrost, which generates lateral heat fluxes from warm to cold faces.

- MAGST around a single rock peak is controlled by micro-meteorological parameters (variable cloud formation from year-to-year) when the rock face is snow free, and by local accumulations where there is snow on the face. Snow-free areas and snow-covered areas can show opposite trends. 
- Surface temperature data confirm that thin (notinsulating) snow cover can lower the surface temperature due to the low snow surface albedo.

Our results also extended the results of previous studies:

- Sensors with thick snow cover showed evidence of a similar thermo-insulation effect to that found on gentle mountain slopes, with smoothing of daily temperatures in winter, a melting period marked by constant surface temperature of around $0^{\circ} \mathrm{C}$, reduced freezing of the active layer in winter, and delayed thawing of the active layer in summer.

- Thick snow accumulations warm MAGST of shady areas and increases interannual changes compared with sunny areas which are cooled by snow blocking solar radiation, and where interannual changes are reduced by the balance between the opposite effects of thermoinsulation and strong albedo.

- Open fractures have a strong, localized cooling effect, possibly due to air ventilation within the fracture. This cooling effect is greater in winter and the heat sink mainly affects the $3-4 \mathrm{~m}$ below the fracture.

\section{Further developments}

The thermal characteristics of the AdM illustrate the complexity of the processes controlling the thermal regime of shallow layers in rock wall permafrost. Modelling these processes represents a major challenge but the data presented here provide a step towards achieving this goal. Studies into the controlling effect of snow cover are needed in order to determine the impact of thick accumulations and summer snow fall on ALT and permafrost changes. The current research project has already collected a large amount of data, including picture showing the evolution of the south and northeast faces of the AdM, snow-stake measurements, and borehole records. Further analyses of these data would help improve understanding of rockfall activity. Research into latent heat consumption in compact bedrock may also provide insight into ALT thickness and timing on some snowcovered rock walls, and into permafrost evolution over short timescales. The BH_N fracture could be used to investigate non-conductive heat transfers, for example by developing a heat conduction scheme. Ground-penetrating radar measurements of the northwest face, including BH_N, offer a detailed picture of the bedrock discontinuities and provide useful additional data for developing a heat flow model integrating bedrock structure. The combined use of crack-meters, air temperature measurement, and borehole data provides a promising avenue for developing understanding of the thermal and mechanical factors affecting rock wall instabilities.

The data set presented here was used for evaluation of statistical and numerical models designed to map the distri- bution of permafrost in the Mont Blanc Massif (Magnin et al., 2015) and to predict the distribution and evolution of the temperature field at the AdM over the next century (Noetzli et al., 2015). The statistical model will be used to determine bedrock temperatures and the related permafrost thermal regime at rockfall locations in order to analyse the relationship between bedrock temperature and rock failures.

Acknowledgements. We would like to thank S. Gruber, U. Morra di Cella, E. Cremonese and E. Malet, for their help with equipment installation and data acquisition at the Aiguille du Midi. The Chamonix Compagnie des Guides provided invaluable assistance with the drilling operations. We would also like to thank the Compagnie du Mont Blanc (especially E. Desvaux) for allowing access to the site, and Météo France for providing air temperature data. We also thank A. Hasler and an anonymous reviewer for their useful comments and recommendations. The English text was corrected by P. Henderson. This work was supported by the Region Rhône-Alpes (CIBLE programme).

Edited by: T. Zhang

\section{References}

Allen, S. K., Gruber, S., and Owens, I. F.: Exploring steep bedrock permafrost and its relationship with recent slope failures in the Southern Alps of New Zealand, Permafrost Periglac., 20, 345356, doi:10.1002/ppp.658, 2009.

Boeckli, L., Brenning, A., Gruber, S., and Noetzli, J.: Permafrost distribution in the European Alps: calculation and evaluation of an index map and summary statistics, The Cryosphere, 6, 807820, doi:10.5194/tc-6-807-2012, 2012.

Deline, P.: Recent Brenva rock avalanches (Valley of Aosta): new chapter in an old story? Supplementi di Geografia Fisica e Dinamica Quaternaria, 5, 55-63, 2001.

Deline, P., Alberto, W., Broccolato, M., Hungr, O., Noetzli, J., Ravanel, L., and Tamburini, A.: The December 2008 Crammont rock avalanche, Mont Blanc massif area, Italy, Nat. Hazards Earth Syst. Sci., 11, 3307-3318, doi:10.5194/nhess-11-33072011, 2011.

Deline, P., Gardent, M., Magnin, F., and Ravanel, L.: The morphodynamics of the Mont Blanc massif in a changing cryosphere: a comprehensive review, Geogr. Ann. A, 94, 265-283, 2012.

Fischer, L., Kääb, A., Huggel, C., and Noetzli, J.: Geology, glacier retreat and permafrost degradation as controlling factors of slope instabilities in a high-mountain rock wall: the Monte Rosa east face, Nat. Hazards Earth Syst. Sci., 6, 761-772, doi:10.5194/nhess-6-761-2006, 2006.

Gruber, S. and Haeberli, W.: Permafrost in steep bedrock slopes and its temperature related destabilization following climate change, J. Geophys. Res.-Earth., 112, F02S13, doi:10.1029/2006JF000547, 2007.

Gruber S. and Haeberli W.: Mountain permafrost, in: Permafrost soils, Margesin R, Springer, Berlin Heidelberg, 16, 33-44, 2009.

Gruber, S., Peter, M., Hoelzle, M., Woodhatch, I., and Haeberli, W.: Surface temperatures in steep alpine rock faces: a strategy for regional-scale measurement and modelling, in: Proceedings of 
the 8th International Conference on Permafrost, edited by: Arenson, L., Zürich, 325-330, 2003.

Gruber, S., Hoelzle, M., and Haeberli, W.: Permafrost thaw and destabilization of Alpine rock walls in the hot summer of 2003, Geophys. Res. Lett., 31, L13504, doi:10.1029/2004GL020051, 2004a.

Gruber, S., Hoelzle, M., and Haeberli, W.: Rock-wall temperatures in the Alps: modelling their topographic distribution and regional differences, Permafrost Periglac., 15, 299-307, doi:10.1002/ppp.501, 2004b.

Gubler, S., Fiddes, J., Keller, M., and Gruber, S.: Scaledependent measurement and analysis of ground surface temperature variability in alpine terrain, The Cryosphere, 5, 431-443, doi:10.5194/tc-5-431-2011, 2011.

Hanson, S. and Hoelzle, M.: The thermal regime of the active layer at the Murtèl rock glacier based on data from 2002, Permafrost Periglac., 15, 273-282, doi:10.1002/ppp.499, 2004.

Harris, S. and Corte, A.: Interactions and relations between mountain permafrost, glaciers,snow and water, Permafrost Periglac., 3, 103-110, 1992.

Hasler, A., Gruber, S., and Haeberli, W.: Temperature variability and offset in steep alpine rock and ice faces, The Cryosphere, 5, 977-988, doi:10.5194/tc-5-977-2011, 2011a.

Hasler, A., Gruber, S., Font, M., and Dubois, A.: Advective heat transport in frozen rock clefts - conceptual model, laboratory experiments and numerical simulation, Permafrost Periglac., 22, 378-349, doi:10.1002/ppp.737, 2011b.

Hipp, T., Etzelmüller, B., and Westermann, S.: Permafrost in Alpine Rock Faces from Jotunheimen and Hurrungane, Southern Norway, Permafrost Periglac., 25, 1-13, doi:10.1002/ppp.1799, 2014.

Hoelzle, M., Wegmann, M., and Krummenacher, B.: Miniature temperature dataloggers for mapping and monitoring of permafrost in high mountain areas: first experience from the Swiss Alps, Permafrost Periglac., 10, 113-124, doi:10.1002/(SICI)10991530(199904/06)10:2<113::AID-PPP317>3.0.CO;2-A, 1999.

Huggel, C., Caplan-Auerbach, J., and Wessels, R.: Recent extreme avalanches triggered by climate change, EOS, Transactions American Geophysical Union, 89, 469-470, 2008.

Huggel, C., Zgraggen-Oswald, S., Haeberli, W., Kääb, A., Polkvoj, A., Galushkin, I., and Evans, S. G.: The 2002 rock/ice avalanche at Kolka/Karmadon, Russian Caucasus: assessment of extraordinary avalanche formation and mobility, and application of QuickBird satellite imagery, Nat. Hazards Earth Syst. Sci., 5, 173-187, doi:10.5194/nhess-5-173-2005, 2005.

Krautblatter, M., Huggel, C., Deline, P., and Hasler, A.: Research Perspectives on Unstable High-alpine Bedrock Permafrost: Measurement, Modelling and Process Understanding, Permafrost Periglac., 23, 80-88, doi:10.1002/ppp.740, 2011.

Juliussen, H. and Humlum, O.: Towards a TTOP ground temperature model for mountainous terrain in central-eastern Norway, Permafrost Periglac., 18, 161-184, doi:10.1002/ppp.586, 2007.

Kukkonen, I. T. and Safanda, J.: Numerical modelling of permafrost in bedrock in northern Fennoscandia during the Holocene, Global Planet. Change, 29, 259-273, 2001.

Leloup, P. H., Arnaud, N., Sobel, E. R., and Lacassin, R.: Alpine thermal and structural evolution of the highest external crystalline massif: The Mont Blanc. Tectonics, 24, TC4002, doi:10.1029/2004TC001676, 2005.
Le Roy, M.: Reconstitution des fluctuations glaciaires holocènes dans les Alpes occidentales, Thèse de Doctorat de Géographie, Université de Savoie, Le Bourget du Lac, 344 pp., 2012.

Luetschg, M., Lehning, M., and Haeberli, W.: A sensitivity study of factors influencing warm/thin permafrost in the Swiss Alps, J. Glaciol., 54, 696-704, 2008.

Magnin, F., Brenning, A., Bodin, X., Deline, P., and Ravanel, L.: Statistical modelling of rock wall permafrost distribution: application to the Mont Blanc massif, Géomorphologie, accepted, 2015.

Noetzli, J., Gruber, S., Kohl, T., Salzmann, N., and Haeberli, W.: Three-dimensional distribution and evolution of permafrost temperatures in idealized high-mountain topography, J. Geophys. Res.-Earth, 112, F02S13, doi:10.1029/2006JF000545, 2007.

Noetzli, J., Christiansen, H. H., Guglielmin, M., Romanovsky, V. E., Shiklomanov, N. I., Smith, A. L., and Zhao, L.: Permafrost thermal state, in: State of the Climate in 2013, Bull. Am. Meteorol. Soc., 95, S15-S17, 2014a.

Noetzli, J., Ravanel L., and Deline P.: Combining measurements and modelling to describe the permafrost conditions at the Aiguille du Midi (3842 m a.s.l., Mont Blanc Massif), The Cryosphere, in preparation, 2015.

PERMOS: Permafrost in Switzerland 2002/2003 and 2003/2004, in: Glaciological Report (Permafrost) No. 4/5 of the Cryospheric Commission of the Swiss Academy of Sciences, edited by: Vonder, Mühll, D., Zürich, 121 pp., 2007.

PERMOS: Permafrost in Switzerland 2008/2009 and 2009/2010, in: Glaciological Report (Permafrost) No. 10/11 of the Cryospheric Commission of the Swiss Academy of Sciences, edited by: Noetzli, J., Zürich, 95 pp., 2013.

Pogliotti, P.: Influence of Snow Cover on MAGST over Complex Morphologies in Mountain Permafrost Regions. PhD thesis, Turin, Italy, Università degli Studi di Torino, 79 pp., 2011.

Ravanel, L. and Deline P.: Climate influence on rockfalls in highAlpine steep rock walls: the north side of the Aiguilles de Chamonix (Mont Blanc massif) since the end of the "Little Ice Age", The Holocene, 21, 357-365, doi:10.1177/0959683610374887, 2010.

Ravanel, L., Allignol, F., Deline, P., Gruber, S., and Ravello, M.: Rock falls in the Mont Blanc Massif in 2007 and 2008, Landslides, 7, 493-501, 2010.

Ravanel, L., Deline, P., Lambiel, C., and Vincent C.: Intability of a high Alpine rock ridge: the lower Arête des Cosmiques, Mont Blanc massif, France, Geogr. Ann. A, 95, 51-66, doi:10.1111/geoa.12000, 2012.

Romanovsky, V. E., Smith, S. L., Christiansen, H. H., Shiklomanov, N. I., Streletskiy, G. A., Drozdov, D. S., Malkova, G. V., Oberman, N. G., Kholodov, A. L., and Marchenko, S. S.: Terrestrial permafrost, in: State of the Climate in 2013, Bull. Am. Meteorol. Soc., 95, S139-S141, 2014.

Smith, M. W. and Riseborough, D. W.: Permafrost monitoring and detection of climate change, Permafrost Periglac., 7, 301309, doi: 10.1002/(SICI)1099-1530(199610)7:4<301::AIDPPP231> 3.0.CO;2-R, 1996.

Smith, M. W. and Riseborough, D. W.: Climate and the limits of permafrost: a zonal analysis, Permafrost Periglac., 13, 1-15, doi:10.1002/ppp.410, 2002. 
Wegmann, M., Gudmundsson, G. H., and Haeberli, W.: Permafrost changes in rock walls and the retreat of Alpine glaciers: a thermal modelling approach, Permafrost Periglac., 9, 23-33, 1998.
Williams, P. J. and Smith, M. W.: The frozen earth, Studies in polar research, Cambridge University Press, Cambridge, 306 pp., 1989. 